\title{
Research on Tourism Promotion of Shandong Zhucheng Dinosaur National Paleontologic Geopark
}

\author{
Xiaoyan Zhai, a \\ ${ }^{1}$ Zaozhuang University, Zaozhuang, Shandong, China \\ azxy1864@126.com
}

Keywords: National Paleontologic Geopark; Tourism Development; Problems; Strategies.

\begin{abstract}
There're 27 national paleontologic geoparks in our country which accounting for $12.95 \%$ of the total geoparks, and the geological resource values of which are very high. However, in terms of tourism resources, they are not so perfect. The important ways for the national paleontologic geoparks to maintain sustainable development are pushing the limitation of geological tourism resources; rapid development of tourism; increase tourism economic benefits; provide financial support to geological resource protection and enhance self-hematopoietic ability. Take the case of Shandong Zhucheng Dinosaur National Paleontologic Geopark, this paper analyzes the problems exiting in tourism development, then we come up with a series of tourism advancement strategies..
\end{abstract}

\section{Introduction}

Shandong Zhucheng Dinosaur National Paleontologic Geoparks is located in Zhucheng city, Shandong province. It riches in resources of dinosaurs fossils and Is the world's largest burial site of dinosaur fossils. Zhucheng city is named as china dragon city.

\section{General Situation of Shandong Zhucheng Dinosaur National Paleontologic Geoparks}

Geographical Location. Shandong Zhucheng Dinosaur National Paleontologic Geoparks is located in Zhucheng city. Zhucheng are at the border of Taiyi Mountains and wei jiao plain. Qingdao is on the east of zhucheng. Rizhao is on the south. Linyi is on the west. Gaomi and Anqiu are on the north. It is located in the city one hour transportation circle in Rizhao, Weifang and Qingdao.

Traffic Condition. The park boasts convenient transportation and geographical advantage. It is $10 \mathrm{~km}$ away from zhucheng city, $290 \mathrm{~km}$ west to jinan, $100 \mathrm{~km}$ east to Qingdao. It is in west of jinghu and jingfu highway and in the north of jiaoji railway. Qinglan highway and jiaoxin railway throughout zhucheng city. Moreover, the park is nearby the main highway, such as S222、S220、 S217、S329 and so on. Thus accessibility of it is strong.

Weather and Climate. Zhucheng is located in southeast of mountain areas of middle southern of Shandong province. The climate of the city belongs to the eastern warm temperate semi-humid continental climate characterized by hot and rainy summers and cold and dry winters. So it has four distinct seasons. Annual average temperature is 12.4 , an average annual rainfall is $735.5 \mathrm{~mm}$.

River System. Juan river flowing from south to the north runs through south and north along the west of the park. The river is meandering and keeps running all the year round.

Landform. The park is located in the field transiting hill to plain. The surrounding terrain is flat. The sea level elevation is between $70 \mathrm{~km}$ and $100 \mathrm{~km}$. the park is in denudational landform.

\section{The Problems Exiting in T, Development}

Low Level of Development of Tourism Resources. Low level of development of tourism resources is mainly embodied in the following three aspects: Firstly, Other tourism resources except for geological relics of dinosaurs. Available tourism resources such as forest, mountain and river have not been fully developed. The number of tourist only attracted by the geological relic resources 
is limited. Secondly, levels of utilization of geological relics resources is at the early stages of display and sightseeing. it is also due to the fact that this park belongs to national paleontologic parks. Thirdly, campus tourism project are single, tourism projects lack of participation and entertaining. So tourists have this kind of psychological feelings the value is out of the ticket price. Meanwhile it decreases the satisfaction of tourists, shortens tourists stay time and lows revisit rate. At last, it results in poor economic efficiency. All is not conducive to the protection of the geological relic resources and intensified the contradiction between geological park tourism resources development and protection.

The Poor of Tourist Service Facilities. With the development of tourist industry of zhucheng, dinosaurs culture brand effect appeared gradually, infrastructure and supporting services of geological park are serious short. Such as visitor center has not yet been built, guide system were made roughly, boundary tablets and boundary markers have not been found in the park geological relics reserves and park boundary . The national geological park reception ability and environment capacity of Zhucheng Dinosaur National Paleontologic Geoparks has been affected.

Single Form of Tourism Interpretation. At present, the interpretation personnel quantity is not enough to cope with tourist receipts, the quality of interpretation should be improved; Placards form is single and simply to show phenomenon. It can't afford to inspire visitors to further explore interest. Therefore, the role of popular science is not fully played.

Deficiency of Whole Tourism Marketing. In Zhucheng Dinosaur National Paleontologic Geoparks, the geological museum, fossilized dinosaur jian are dispersed, the complete tourist route is lack between scenic spots in the park. It makes the visitors can not feel the overall concept of geological park. Ttourist can easily regard various geological sites as optional sites.

Rough Protection Facilities of Geological Resources. This park has a large number of Dinosaur fossils. Dinosaur fossils are buried intensively. Most of the fossils have been protected in its places. The difficulty of waterproof and windproof is quite high. Workload of protection is big. Although, zhucheng local government formulated the "zhucheng dinosaur fossil protection scheme", but because of lack of funds, the protection of geological relics resources is still weak. Meanwhile the protection of the public consciousness and understanding of geological relics is not high. This will directly influence the geological relics protection.

Incomplete Functions of Management Institutions. At the present time, Geological park management office, listed in zhucheng dinosaur culture research center, implement "a set of personnel, two pieces of brand" management system is responsible for Daily management work of Zhucheng Dinosaur National Paleontologic Geoparks. Due to the management system, at present most of geological park service personnel are professional dinosaur fossils. However, Personnel have professional background knowledge of tourism are short. Above all lead to geological park service function is not perfect, they are little or basically do not participate in zhucheng dinosaur national geological park, the planning of tourism, tourist marketing, tourism product development, etc.

\section{Tourism Advancement Strategies of Shandong Zhucheng Dinosaur National Paleontologic Geoparks}

Doing Tourism Planning Well. The government should formulate Special tourism planning. Zhucheng Bureau of Land and Resources can cooperate with tourism administration. They should invite domestic and foreign well-known expert professor who can work together to develop zhucheng dinosaur national geopark tourism development planning for a long time. Zhucheng dinosaur national geological park can invite professional tourism planning company. They should do the market survey fully, find accurate market positioning, excavate recreational tourism resources, design the design methods creatively, set up reasonable management operations and overall development mode of system, make the scientific layout and reasonable planning of tourist area.

Completing the System of Tourism Product. Although the zhucheng dinosaur national geological park have developed some distinctive tourism products, but the level of development is still relatively low and the width and depth of the tourism product development is not enough. According to different market segments, different tourism products should be designed and developed. The development concepts emphasis on innovation, creative tourism products should be 
designed, such as increased leisure tourism products, holiday tourism products, tourism souvenirs, increase tourism projects.

Making Greater efforts for Building Park. Firstly, the park should strengthen the construction of tourist service facilities, dining facilities, tourist accommodation facilities of tourism and tourist road facilities. Secondly, perfect the system. This park applies technology to geological park tourism placards to change traditional explanation form, such as hand touch screen placards, the three-dimensional image of dinosaurs. By this way, more images of varying forms of different kinds of dinosaurs will be showed intuitively to visitors. Thirdly, to construct a high quality tourism interpretation team for this park. The tourism interpretation personnel should be trained termly. And the park should holds a series of lectures to increase interpretation personnel museum of paleontology, geology, and psychology related professional knowledge and update knowledge base on the staff. Meanwhile the park should speed up the introduction of foreign language tour guides to meet the demand of foreign tourists in the geological park. In addition, the team of experts explanation should be set up to meet the demand of different levels of interpretation. At the same time volunteer team can be established. By this way, more paleontological related professional knowledge of people can be involved in the popular science propaganda work. Let them to use scientific explanation facilities, and make scientific explanation that is easily understood for the general tourists.

Increasing the Intensity of Tourism Marketing. Distinct image marketing should be made. It should rich media marketing types, expand marketing channels, make full use of new media marketing. Through new media platforms such as weibo, WeChat, the park will carry out a series of activities about activity planning, product promotion, brand promotion and so on to increase the interaction of zhucheng dinosaur national geological parks and tourist. At the same time, the park should strengthen the scenic spot joint marketing and the cooperation with other geological park in the province to make market promotion.

Enhancing Protection of Geological Relics Resources. high technology can be fully used to protect the fossil according to class. the dynamic database of geological remains, dynamically monitoring geological park resources can be established. It is urgent to carry out the "shandong zhucheng dinosaur fossil protection scheme" and increase the protection funds.

Raising the Level of Financial Support. The park should make greater effort in inviting and attracting outside investment. It is essential for the projects attracting funds difficultly to make preferential and special policy to get creative tourism projects, such as a series of film and television production, cultural tourism, sports leisure. Social capital investment should be encouraged. Encourage and guide the social capital participate in the tourism development and protection of geological park in a variety of ways. Only by this means can it make tourism investment hot spot and focus and invert resources superiority into capital superiority. At last it can achieve the best combination of resources and money. Expand diversified investment and financing channels. the geological park can take tourism projects as the carrier and take the capital as the link to encourage all kinds of investment main body through equity participation, joint venture cooperation, franchising and other methods. All kinds of financial institutions should favour key tourism projects.

\section{References}

[1] Alexandrowicz Z, Urban J, et al. Geological Values of Selected Polish Properties of the UNESCO World Heritage List[J]. Geoheritage,2009,1(1):43-52

[2]Zouros N. The European Geoparks Network Geological Heritage Protection and Local Development[J].Episodes,2004,27(3):165-171

[3]Wartiti M E, Malaki A, et al.Geosites Inventory of the Northwestern Tabular Middle Atlas of Morocco[J].Environmental Geology,2008,55:415-422. 
[4]Dowling R.Geotourisms Contribution to Local and Regional Development[A]. in: Carvalho C $\mathrm{N}$, Rodrigues J, et al. Geotourism \& Local Development[C].. Portugal: Printmor-Rio Maior,2009:15-37

[5]Alexandrowicz Z, Urban J, et al. Geological Values of Selected Polish Properties of the UNESCO World Heritage List[J]. Geoheritage,2009,1(1):43-52

[6] Hull C M. Trends in ocean and coastal tourism-the end of the last frontier? Ocean\&Coastal Management, 2001(44):601-618

[52] Lindemberg Medeiros de Araujo, Bill Bramwell. Partnership and regional tourism in tourism

[7] The European Geoparks: European Geoparks Network.European Geoparks Magazine issue 111 2001,17-26

[8]Csikszentmihalyi,M. and Csikszentmihalyi. Optimal Experiences[M]. Cambridge: Cambridge University Press,1988

[9] Ibrahim Komoo. Geoheritage conservation and its potential for Geopark development in Asia-Oceania[R]. Bangi Malaysia: Institute for Environment and Development(LESTARI)National University of Malaysia,2005.

[10] Glasser N. Conservation and management of the earth heritage resource in Great Britain[J].Journal of Environmental Planning and Management. 2001,44,6,889-906.

[11] Andreas Megerle. National Geoparks and Geotourism in Germany Framework and Case Study Baden-Wuerttemberg and Swabian Alb[R]. Department of Geography, University of Tuebingen,2004 